\title{
Dr. Ezzat Abouleish: Academician and Artist, Pioneer of Obstetric Anesthesia
}

$\mathrm{M}$ y wife, Skina H. Fadel, MD, and I are graduates (1964 and 1960, respectively) of Ain Shams Faculty of Medicine in Cairo, Egypt. Dr. Ezzat Abouleish was our senior. He graduated from the same school in 1954 and had his residency training there. He joined the faculty of the Anesthesiology Department. He obtained a diploma in anesthesia, a diploma in medicine, and a MD (PhD equivalent) in anesthesia. He was an associate professor when he decided to immigrate to the United States in 1968. At that time, we never thought our paths would cross again. Actually, at that time we never thought that we would move to the United States, but here we all are.

My wife chose to become an anesthesiologist when we came to the United States, and thus met Dr. Abouleish frequently at the annual meetings of the American Society of Anesthesiology. Also, Dr. Abouleish joined IMANA about 30 years ago as a life member, and we met him in our annual conventions.

In the United States, Dr. Abouleish served at Case Western Reserve University from 1968 to 1970, the University of Pittsburgh from 1970 to 1982, and the University of Texas-Houston from 1982 until present. For the last 20 years, he has been a professor of anesthesiology with special interest and expertise in obstetric anesthesia. Since 2001, he has served as professor emeritus.

Dr. Abouleish is a pioneer of obstetric anesthesia. He helped advance this specialty, and, in particular, the use of spinal anesthesia in obstetrics. He wrote the textbook "Pain Control in Obstetrics" in 1977, which was considered by many as a standard textbook and was translated into many languages. He taught obstetric anesthesia to hundreds of residents and many national and international fellows. In addition, he authored other books, many chapters, and more than 100 articles.

In Islamic literature, Dr. Abouleish wrote two outstanding articles that were published in JIMA. The first was entitled "Contributions of Islam to Medicine" and was published in 1979.1 This article covered the early history of Islam, its spread to most of the known world at the time, the positive role of Islam on culture and science, and the factors that contributed to this positive role. It addressed the status of

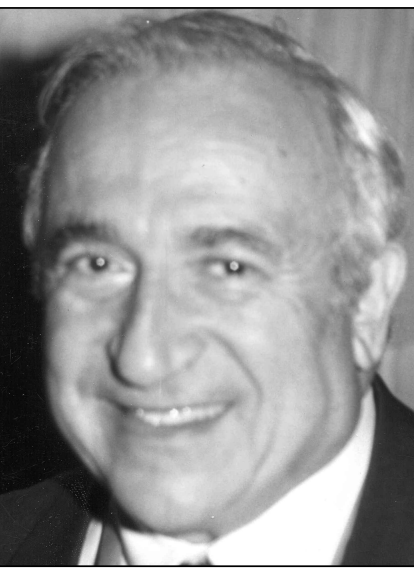

Ezzat Abouleish, MD medicine before Islam, both from the viewpoint of manpower and hospitals. He then described the characteristic features of hospitals in the Islamic civilization and described some of the most famous hospitals in that era in Dimishq (Damascus), al-Quds (Jerusalem), Baghdad, al-Qāhira (Cairo), al-Qayrawān in modern-day Tunisia, Marākish in Morocco, and in Ghirnāța (Granada) in al-Andalus (Iberian Peninsula). He described Islamic medical ethics, especially the personal characteristics of the physician as well as his obligation towards patients, community, colleagues, and assistants. He then gave a short biography of a few of the most famous physicians of the Islamic civilization, i.e., alRāzi, al-Zahrāwī, ibn Sīna, ibn Rushd, Mūsa ibn Maymūn, and ibn al-Nafīs. This article has been quoted as reference to this topic for 26 years as shown by Google database.

The second article, entitled "The Iran-Iraq War has to End", was published in $1988^{2}$ and is as pertinent now with the catastrophic events in Iraq of today as it was then after 8 years of the Iran-Iraq war.

For the public, he wrote the book "Moments with the Pen" on work ethics, philosophy, culture, family, spirituality, humor, and romance. This book won the first prize in literature in the 2002 American Society of Anesthesiology annual meeting in San Francisco. 
The book demonstrates how immigrants can and should keep their values and add to them the best of their adopted country. In 2006, he also wrote a book in Arabic entitled "Oh My Son," documented by 22 of his paintings. He advises the younger generation and conveys to them the real spirit of Islam.

In addition to his writings, he is an accomplished artist. In his own words "the medical profession nurtured my keen eye, refined my senses, and tuned my feelings." He added: "I love art, especially calligraphy, because it is not only beautiful but also has a moral and spiritual meaning."

Dr. Abouleish has won many awards and has had many art exhibits. To mention a few, in 2006 he won The People's Choice Award of the National Society of Artists held in Houston; Chosen Exhibitor at Freeman Library of Clear Lake in Texas (the title was Spirituality and Art), the first place award of the art show of the American Society of Anesthesiology held in Chicago; a mural painting with Muslim children displayed at Rice University and entitled "Painting for Peace."

Dr. Abouleish recently completed a project of painting the 99 beautiful names of Allah 4 alt. He has offered to submit one or two of these paintings to each issue of JIMA, and we gratefully accepted his offer. JIMA readers have seen these paintings in the last five issues of JIMA.

In summary, Dr. Abouleish is an excellent clinician, an accomplished academician, and an artist with special contributions to Islamic art.

\section{Profile submitted by}

\section{Hossam E. Fadel, MD, PhD, FACOG \\ Director of Maternal Fetal Medicine \\ University Hospital \\ Clinical Professor \\ Department of Obstetrics and Gynecology \\ Medical College Georgia \\ Augusta, Georgia}

\section{References:}

1. Abouleish, E. Contributions of Islam to Medicine. J Islam Med Assn 1979;10:28-45.

2. Abouleish, E. The Iran-Iraq war has to end. J Islam Med Assn 1988;20:45-6. 